\title{
A MÃo QUE BALANÇA O VERO: UMA PROPOSTA DE LEITURA SOBRE RECEPÇÃO DE ARTE A PARTIR DAS CANÇÕES DE CHICO BUARQUE DE HOLLANDA
}

\section{LUCIANA FERNANDES UCELLI-RAMOS* \\ Maria AmÉlia DALVI ${ }^{* *}$}

\section{Resumo}

Partindo de uma visada particular sobre a arte e a contemporaneidade em que vivemos, propomos uma análise relacionada ao papel desempenhado pela arte na cosmovisão dos sujeitos deste tempo. Para tanto, destacamos como corpus uma poesia musical, que designamos pelo nome "oraliteratura": a canção de Chico Buarque de Hollanda.

Palavras-chave: Canção. Chico Buarque. Sociedade. Contemporâneo. Educação.

\section{INTRODUÇÃO}

A mão que balança o vero, brincadeira-título que comunica com "A mão que balança o berço" - filme de Curtis Hanson (1992) - é mais que um trocadilho intertextual. Aponta para o que se quer discutir aqui. Se os discursos que regem as verdades sociais orientam as vidas humanas, e se bem sabemos que, em geral, acabam por condenar essas vidas à autoanulação, à castração dos desejos e do pensamento livre, é válido propor intervenções na realidade que "balancem" esse vero culturalmente instituído, de modo a deixar, em vez da condenação à reprodução, alternativas ao pensamento.

* Mestre em Letras. Professora da Secretaria Municipal de Educação/SEMED, Guarapari, Espírito Santo, Brasil.

E-mail: lucianafucelli@gmail.com ORCID iD: https://orcid.org/0000-0003-1692-9255.

** Doutora em Educação. Professora da Universidade Federal do Espírito Santo, Vitória, Brasil. E-mail: dalvimariaamelia@gmail.com. ORCID iD: https://orcid.org/0000-0002-87292338 
Tomando como motivação crítica a afirmação de Harvey (1989, p. 50) de que

[... o único caminho para eliminar o fascismo que está na nossa cabeça é explorar as qualidades abertas do discurso humano, tomando-as como fundamento, e, assim, intervir na maneira como o conhecimento humano é produzido e constituído nos lugares particulares em que prevaleça um discurso de poder localizado [...] dedicando-se ao cultivo e aperfeiçoamento da resistência localizada às instituições, técnicas e discursos da repressão organizada,

sugerimos, aqui, a necessidade de se aplicar expressivamente a arte, como mecanismo de reflexão, questionamento e amadurecimento de novas ideias acerca das verdades estabelecidas: não apenas como um discurso entre outros, mas como unidade-síntese de compreensão e fruição. Isso porque compreender a literatura como fundamental à constituição do patrimônio histórico humano-genérico é o primeiro passo para entender sua importância no processo - dialético - de formação humana (DUARTE, 2008; SAVIANI; DUARTE, 2012). A mão que tem a potência de se encarregar de atuar como ferramenta crítica capaz de abalar as verdades da cultura estabelecida deve partir do coração dessa cultura.

Consideremos, porém, dois pontos. O primeiro é levantado por Unger (1998, p. 17): "O poder de descobrir a verdade sobre o mundo não pode se manter dentro das formas de discurso que são seus veículos”. O segundo decorre deste: não há como destacar as células humanas desse confuso capítulo XXI dos séculos para que possam pensar sobre ele. O contemporâneo encontra-se, então, diante de um impasse: precisa pensar de fora dos discursos estabelecidos sobre as relações humanas, mas sofre da impossibilidade de destacar do contexto os sujeitos dessas relações.

Daí a validade de pensar mais ativamente no "papel” da arte: embora a literatura não tenha uma finalidade prática imediata e definida a priori, ela exerce uma função insubstituível de refletir a realidade em sua unidade contraditória - não aquela camada imediata e mecânica da realidade, não os fenômenos da superfície da vida humana, não a mera cópia de 
fenômenos fetichizados, invertidos e fragmentados, nem, tampouco, uma abstração desarticulada da vida-mesma, dada como "autossuficiente", mas o estabelecimento de conexões entre aparência e essência, se contrapondo à "vida administrada".

Abreviando e trazendo essa reflexão para o âmbito do literário, a arte opera diretamente sobre a linguagem e as linguagens - mesmo mecanismo de propagação e manutenção dos discursos de poder -, e, portanto, pode inverter, sem maiores necessidades de recodificação, "o feitiço contra o feiticeiro".

Dentro da obra literária, não é o sujeito que se subordina às vicissitudes de uma cultura: no corpo da representação do real pela palavra, a relevância que a arte literária assume para os sujeitos contemporâneos passa por sua necessidade de ver as relações humanas sem o fardo de ter de olhar para elas no papel de "fiscais da moral" que a cultura neles introjeta. A fruição põe-nos, pois, em contato com realidades para as quais podemos olhar diretamente, justamente porque indiretamente pelo anteparo ficcional. Nas palavras de Menezes (1994, p. 170-171), isso seria a efetivação da hipótese de que

[...] a pregação de uma fruição estética, sensorial, dos fatos da vida, produziria, na verdade, a redução da capacidade crítica (entendida enquanto reflexão intelectual e lógica segundo preceitos da cultura) no enfrentamento dos problemas e contradições dessa realidade [...]. A estética, nesse momento de redefinição de sua natureza e campo de atuação, não deve ser vista somente como disciplina filosófica, mas deve assumir um papel de esfera da experiência, como dimensão da existência que assume, assim, um valor emblemático, de modelo mesmo, para pensar a historicidade em geral.

É importante acrescentar que, como "livro é cultura", "cinema é cultura", "música é cultura", não se olha para arte do texto como o ser cultural que se é: imerge-se nessa cultura paralela - poder paralelo, e, como diria Zizek (2003, p. 113), "terrorista, por resistir à ordem”. 
Se, segundo Baudrillard (2003, p. 36), "nossa sociedade se empenha em fazer com que tudo vá bem, e que a cada necessidade corresponda uma tecnologia", e, "nesse sentido, toda tecnologia está do lado do bem, isto é, da realização de um desejo real", a presente empreitada de busca por novas tecnologias ganha mais uma, e última, confirmação de validade. Vista por esse prisma, a arte literária apresenta-se como esperança de tecnologia alternativa ao pensamento sobre o estar no mundo, sobre a riqueza dos detalhes que compõem o todo-vida, além trazer em seu bojo inúmeras outras possibilidades de ampliar nossa visão acerca daquilo que se vivencia. Abrir novas portas para o pensamento, ao mesmo tempo que propicia prazer, é um dos maiores, senão o maior, préstimo da literatura aos homens do espaço-tempo em que vivemos.

O artista, nesse contexto, é o forasteiro que, vindo de campos alheios aos das formalidades prescritas, nos oferece a possibilidade de encontrar algo além do simples ordinário. E não quero basear essa afirmativa numa ilusão de conferir ao artista um status de responsabilidade sobre o homem comum, nem mesmo propor que entre aquele e este se configure uma relação entre protegidos e heróis. Quero fazer coro, para o engrandecimento do homem e da arte da palavra, a Hans Robert Jauss - na interpretação de Luiza Lobo -, defendendo que "a história literária deveria ser, ao lado de outras artes, um processo de contínua libertação, buscando emancipar o homem das restrições que lhe são impostas pela natureza, a religião e a sociedade" (LOBO, 1992, p. 234):

A história literária só se realiza quando integra a experiência cotidiana do leitor, e, inversamente, quando a experiência literária deste modifica seu comportamento social. Assim, Jauss conclui que a literatura não pode ser reduzida a "uma arte de representação". Ele deseja resgatar a dimensão social da literatura, ao lado das outras artes, como agente da derrubada de tabus morais e como forma de transformação social (LOBO, 1992, p. 235).

O grau de alcance de visão do artista é significativamente maior do que o possível à vista turva dos "meninos do destino", porque, como 
reflete Bakhtin (2015, p. XXXIII) “quando o homem está na arte não está na vida, e vice-versa”.

As lentes pelas quais o artista vê o mundo variam de cor, grau e função, de acordo com a situação enunciativa e discursiva. No fim das contas, é esse efeito "multifocal" que lhe dá a lucidez, pela via dum discurso de "loucura" (destoante do olhar da cultura tradicional e do senso comum), a que raramente o homem comum é capaz de se prestar.

É importante observar com cuidado que a possibilidade de tecer seus próprios critérios requer responsabilidade de criação por parte do artista e de seleção por parte do sujeito-leitor. Nas palavras de Bakhtin (2013, p. 34),

A vida e a arte não devem só arcar com a responsabilidade mútua, mas também com a culpa mútua. $O$ poeta deve compreender que sua poesia tem culpa pela prosa trivial da vida, e é bom que o homem da vida saiba que a sua falta de exigência e a falta de seriedade das suas questões vitais respondem pela esterilidade da arte. [...] E nada de citar "inspiração" para justificar a irresponsabilidade. A inspiração ignorada pela vida não é inspiração, mas obsessão.

Também há que se considerar que, quando as lentes do artista responsável são emprestadas ao homem comum, os efeitos podem variar. Toda essa nova possibilidade de modos de sentir o mundo que se descortina requer postura, escolha e decisão.

No âmbito das reflexões sobre o leitor e sobre a recepção, interessa chamar a atenção para algumas importantes referências.

Barthes (1977, p. 32) postula que "O texto tem de me dar a prova de que me deseja. Essa prova existe: é a escrita. A escrita é isto: a ciência das fruições da linguagem, o seu kamasutra (desta ciência existe um só tratado: a própria escrita)". Santerres-Sarkany (1991, p. 55, 57) pontua que "a problemática central do leitor está atualmente na ordem do dia" e que "A oraliteratura (termo recomendado por Maximilien Laroche, em La littérature haïtienne, Montreal, 1981) é ainda hoje, em certos países, o modo literário principal e dominante”. 
Aquilo a que Maximilien Laroche (1993) recomenda chamar de "oraliteratura" são as formas de expressão que não se restringem à escrita. São aquelas que já nascem ou que são forjadas com a finalidade de serem veiculadas com entonação, timbre e ritmos orais, uma vez que, conforme assevera Santerres-Sarkany (1991, p. 59), "o oral é veículo da opinião cultural; o aspecto mais claro do saber passa por trocas que se fazem em voz alta".

A partir desses posicionamentos, lançamo-nos a ilustrar nossa proposição de analisar o papel influente que a arte exerce sobre a visão de mundo dos seres culturais que somos. Para tanto, buscamos por uma arte que desejasse o fruidor. Precisávamos nos ancorar em obras que já se imbuíssem do papel a que aqui referimos, e que considerassem o caráter de predominância da oraliteratura. Então, para desenvolver nosso intento, escolhemos como corpus o universo musical de Chico Buarque de Holanda.

Dada a necessidade de pensar no como da ocupação desse lugar pela arte literária e cancional, nos dedicamos, neste momento, a apontar no corpo do texto alguns dos movimentos da mão que o elabora, seus cortes, suas máscaras e os sinais em que se apoia - em suma, as formas e representações empregadas para dominar pela linguagem qualquer coisa que se interponha no caminho entre o receptor e a fruição, em face do recebido. O que, então, realizaremos, é uma investigação dos mecanismos tramados e empregados por um autor, e sua habilidade para conduzir qual a mão de um diretor de cinema - e aqui se justifica brevemente o jogo intertextual do título - o olhar, o desejo e mesmo as verdades (conceitos internalizados) do receptor para um ponto em que seja possível a interação deste com a verdade da obra, na composição de um sentido dela - e para ela.

\section{UMA ANATOMIA DA MÃO}

A representação, para nós, daquilo que somos, isto é, a composição de perfis humanos pela mão de um autor responsável, ganha em 
grandeza e em profundidade quando se prende menos à conformação das aparências do que às próprias relações que constituem o humano: as relações com o outro, com o meio e consigo, já que, com isso, propicia-se uma representação do real que se oferece aos olhos da atualidade como um termo de oposição e uma alternativa àquilo que Eagleton (2002, p. 318) delineia como sendo o perfil de nosso tempo, ou seja, o pobre retrato de um tempo que " $[\ldots]$ rejeita a profundidade metafísica, em favor de uma espécie de superficialidade forjada, jocosidade e falta de afeto; [...] prazeres, superfícies e intensidades fugazes".

Aqui, vale a pena referir o conceito de Bakhtin (2013, p. 33) de que "os três campos da cultura humana - a ciência, a arte e a vida - só adquirem unidade no indivíduo que os incorpora à sua própria unidade", o que leva à conclusão de que a ciência literária, o gozo que propicia, e a vida que lhe serve de fonte e público se unificam no momento em que o fruidor as incorpora à sua experiência.

Comecemos pela denúncia da própria incapacidade de ver: a arte, forasteira, descortinando o quanto se convive com a "cegueira" com esse olhar culturalmente obnubilado, o quanto perdemos com isso e o quanto somos incapazes de aceitar, nas muitas oportunidades que temos, a ajuda que se nos coloca ao alcance. Nós, personificados na fragilidade de "Carolina" ${ }^{1}$ :

Carolina

Nos seus olhos fundos

Guarda tanta dor

A dor de todo esse mundo

Eu já lhe expliquei que não vai dar

Seu pranto não vai nada mudar

Eu já convidei para dançar

É hora, já sei, de aproveitar.

Lá fora, amor

Uma rosa nasceu

1 Canção composta em 1967 e gravada em 1968 no disco "Chico Buarque de Holanda - vol. 3". 
Todo mundo sambou

Uma estrela caiu...

Eu bem que mostrei sorrindo

Pela janela, ói que lindo

E só Carolina não viu.

Carolina

Nos seus olhos tristes

Guarda tanto amor

$\mathrm{O}$ amor que já não existe.

Eu bem que avisei: vai acabar

De tudo lhe dei para aceitar

Mil versos cantei pra lhe agradar

Agora, não sei como explicar

Lá fora, amor

Uma rosa morreu

Uma festa acabou

Nosso barco partiu

Eu bem que mostrei a ela

O tempo passou na janela

E só Carolina não viu

(HOLANDA, 2006, p. 157).

Em "Carolina” evidencia-se a tristeza contemporânea, incapaz de superar o niilismo, e a estagnação que não permite eliminar a tristeza. A opção - com o perdão da dureza - de guardar dor nos olhos, embaça a visão da riqueza do presente que se oferece e do futuro em que se poderia crer: prende-se ao passado, guarda-o. Com a postura de não ver o que se oferece, perde as chances de experimentar florescimentos ("Lá fora, amor / Uma rosa nasceu").

Jogando suas pérolas de água e sal ao nada, perde o momento de se metamorfosear. E os florescimentos se dão sem ela, e fenecem ("Lá fora, amor ( Uma rosa morreu”); a alegria e a ilusão coletivas terminam; e o futuro, que poderia ter sido costurado na hora perdida, zarpa ("Nosso barco partiu”). E só Carolina não viu. Nem as perdas nem os ganhos. Sem esperanças nem frustrações, na nulidade de meramente existir, desperdiça a potencialidade transformadora sua humanidade. 
Uma vida sem riscos, que confia em lágrimas como argumentos, e que não dá crédito à potência das próprias aspirações está fadada à condição de “Carolina”, como nos foi possível notar, não sem incômodo, pela dilatação da realidade engendrada nas lentes a nós emprestadas pela arte.

Numa visada comparativa com a artimanha cinematográfica, o trabalho do artista, na composição da imagem de Carolina, é o de criar um plano passar daquilo que no cinema se designa como PPP - um plano que corta os personagens centrando o foco em detalhes do rosto - ao Plano Geral - escala que, consiste numa ampliação demasiada do ambiente, fazendo ver o personagem como um indivíduo imerso em seu horizonte de possibilidades ${ }^{2}$. O papel que o texto pode vir a desempenhar, então, a posteriori, é o de denunciar de um lado os sujeitos que se fecham em si mesmos e a limitação dos horizontes autoimposta por esse comportamento. De outro lado, por termos uma segunda visão, esta geral, do universo de possibilidades que o sujeito retratado rejeita com esse mesmo comportamento: nós, sujeitos sociais, espelhados naquele -, somos impelidos a tecer sobre ele uma reflexão crítica e que se estende ao nosso próprio estar-no-mundo.

Uma outra faceta das estratégias de representação potencialmente transformadoras é a que se perfaz na composição de personagens e realidades-argumento. Comumente, percebe-se o uso desse recurso quando o objetivo da composição é o questionamento das verdades estabelecidas. Personagens-argumento e realidades-argumento no sentido de que sua própria colocação no universo fictício constitui uma reconfiguração do espaço e dos seres, e emparelha, implicitamente, as verdades do mundo e as verdades da obra, ampliando os poderes destas sobre aquelas.

Isso pode ser ilustrado, por exemplo, numa composição buarquiana que tematiza o Carnaval, a saber, "Vai passar" 3 :

2 Cf. BERNADET, 1980, p. 142.

3 Canção composta em 1984 sobre a melodia de Francis Hime gravada no mesmo ano no disco "Chico Buarque". 
Vai passar nessa avenida o samba popular

Cada paralelepípedo da velha cidade

Essa noite vai se arrepiar

Ao lembrar que aqui passaram sambas imortais

Que aqui sangraram pelos nossos pés

Que aqui sambaram nossos ancestrais

Num tempo, página infeliz da nossa história

Passagem desbotada na memória

Das nossas novas gerações

Dormia a nossa pátria mãe, tão distraída

Sem perceber que era subtraída, em tenebrosas transações

Seus filhos erravam cegos pelo continente

Quebravam pedras feito penitentes

Erguendo estranhas catedrais

E um dia, afinal, tinham direito a uma alegria fugaz

Uma ofegante epidemia que se chamava carnaval

Vai passar

Palmas pra ala dos barões famintos

O bloco dos napoleões retintos

E os pigmeus do Boulevard

Meu Deus, vem olhar

Vem ver de perto uma cidade a cantar

A evolução da liberdade

Até o dia clarear

$\mathrm{Ai}$, que vida boa, olerê!

Ai, que vida boa, olará!

$\mathrm{O}$ estandarte do sanatório geral

Vai passar (HOLANDA, 2006, p. 359).

Um efeito especial da arte, nesta canção, é o de ofuscar o que no real está em primeiro plano nos discursos vigentes. Outro é o de dar visibilidade ampliada àquilo que normalmente fica no plano de fundo, na ala dos figurantes. Tira-se de seu contexto de origem o discurso de reprovação, e se o põe no seio daquilo que, em sua posição normal, esmagaria. Sejamos mais claros. 
Versa, há muito tempo, e mais ainda hoje, um certo discurso social, sobre a necessidade de se questionar a participação do pobre nos festejos carnavalescos. Nesse discurso, levanta-se a afirmativa de que,

[...] com tantas mazelas sociais carecendo de observação e ação por parte do povo que as sofre, é vaidade, e mesmo futilidade, ceder à explosão de prazeres momentâneos, vez que, ao mesmo tempo em que se dão esses eventos, assiste-se a uma fragmentação étnica e cultural" (ARIZA, 2006, p. 73).

Esse discurso é, como atesta Kristeva (1976, p. 129),

[...] por definição, ideológico, e, como tal, funciona [grifo nosso a serviço das ideologias. Daí a utilização que dele fazem as classes dominantes, desejosas de se dar, além da religião, um apoio ideológico suplementar apropriado à palavra da moda.

É mister, segundo a lógica aqui perseguida, propiciar, sobre o discutível, uma discussão. Chico Buarque recorre do argumento discutível, mas vigente, ao conferir à vivência do carnaval pelo pobre valorações positivas.

Ao abordar a série de violências históricas que compuseram a base da formação das comunidades pobres no Brasil, o autor advoga em favor do comportamento delas, tratando sua conduta como um direito adquirido pela via da desgraça. Ressalta que, durante o carnaval, embora famintos, apesar de retintos e a despeito de não terem morada, são barões, napoleões, gigantes. Pinta-se o carnaval, então, sob o signo de um lugar onde se pode viver o sonho de estar no comando - pelo menos da própria vida, escolher ser o que se quiser -; onde o pobre ascende ao lugar do poder; onde existe um ser feliz. Estar no sanatório geral abre, para os sujeitos, o direito de viver segundo o desejo, e, assim, abre-se uma potente via política de subversão da ordem constituída. Com essas máscaras, o autor, ao mesmo tempo que, persuasivamente, dizima resistências de ordem conservadora e moralizadora (ainda quando de base - supostamente - progressista), 
defende o direito à alegria fugaz e destitui de poder - ainda que sem deixar encoberta a ironia daquilo que hoje se considera $a$ "evolução da liberdade" - o discurso social há pouco abordado.

No mais, a apresentação da letra soba forma de samba contribui para burlar as resistências. Reprovar o enredo seria, pela via da lógica, um impedimento à aceitação do próprio trabalho artístico em sua totalidade. No caso de se querer manter o desejo pela obra e ao mesmo tempo sustentar o discurso de poder que a reprova, o procedimento de recepção e aceitação soaria hipócrita. Com esse dispositivo formal-conteudístico, seria posta em evidência uma contradição do eu-leitor e, também, uma contradição social inscrita na própria obra - esta, capaz, por si, de provocar reflexões.

Esse tipo de abordagem é algo que perpassa toda a trajetória de Chico Buarque de Hollanda enquanto compositor. Conforme os estudos de Meneses (1980, p. 98),

A vertente crítica e social direta resvala, muitas vezes, para a sátira, para a paródia. [...]. E um perfil das personagens mais frequentes em suas canções nos levará à figura do marginal, do desvalido.... Uma galeria imensa que engrossará a "romaria dos mutilados" de que se fala em $O$ que será", daqueles que foram mutilados física ou socialmente: os infelizes, as meretrizes, os bandidos, os desvalidos - ao que se vêm acrescentar as mulheres abandonadas, os pivetes, os operários, os pedreiros, o malandro.

É, pois, sobre relações de poder, boa parte da obra de Chico Buarque, e, por isso mesmo, suas criações são matéria perfeitamente adequada aos fins desta análise.

Passemos, então, desta relação com o discurso superior de poder a um trabalho da poesia sobre relações de poder para com alteridades particulares. Para o questionamento das relações de poder particulares, entre tipos de sujeitos específicos, a tática da arte cinematográfica é, comumente, a de pôr num mesmo plano os reprovados e os reprovadores - bem como os recursos de reprovação -, ou a de ridicularizar o discurso 
e seu detentor. Nas duas possibilidades, o efeito perseguido é o de buscar a evidenciação da fragilidade dos conceitos e de seus mantenedores, pela via da verossimilhança com uma verdade que aparente ser mais geral que a da realidade imposta - a da obra. Verossimilhança aqui tomada na defesa de Hansen (1992, p. 21):

O verossímil - o "semelhante ao verdadeiro" - que se fundamenta de direito no verdadeiro, opondo-se ao falso pelo direito do fundamento, como um jogo de força, teorizado por Aristóteles na modelização dos lugares-comuns e seus efeitos persuasivos.

O fundamento da arte se dá como superior ao do real pela sensação de que a realidade da obra é mais abrangente:

$\mathrm{Na}$ vida objetiva, cada fenômeno do aqui e agora, está em conexão com sua essência histórica, mas essa conexão é extensiva, está diluída no oceano da vida. $\mathrm{O}$ artista cria um mundo particular, um pequeno todo bem-acabado, coeso [...], que reflete, de forma intensiva, condensada, aquilo que está disperso na realidade [...] Assim, no mundo particular de cada obra de arte, [...] reflete-se de forma intensificada a realidade da vida social (CORRÊA et al., 2019, p. 24-26).

A contribuição da canção de Chico Buarque para exemplificar esse procedimento se mostra evidente nos giros da "Ciranda da bailarina" ${ }^{4}$.

Procurando bem

Todo mundo tem pereba

Marca de bexiga ou vacina

E tem piriri, tem lombriga, tem ameba

Só a bailarina que não tem

E não tem coceira

Berruga nem frieira

Nem falta de maneira

Ela não tem.

4 Coro infantil composto em 1982 sobre a melodia de Edu Lobo gravada em 1983 no disco "O grande circo místico". 
Futucando bem

Todo mundo tem piolho

Ou tem cheiro de creolina

Todo mundo tem um irmão meio zarolho

Só a bailarina que não tem

Nem unha encardida

Nem dente com comida

Nem casca de ferida ela não tem

Não livra ninguém

Todo mundo tem remela

Quando acorda às seis da matina

Teve escarlatina

Ou tem febre amarela

Só a bailarina que não tem

Medo de subir, gente

Medo de cair, gente

Medo de vertigem quem não tem

Confessando bem todo mundo faz pecado

Logo assim que a missa termina

Todo mundo tem um primeiro namorado

Só a bailarina que não tem

Sujo atrás da orelha

Bigode de groselha

Calcinha um pouco velha

Ela não tem

O padre, também

Pode até ficar vermelho

Se o vento levanta a batina

Reparando bem, todo mundo tem pentelho

Só a bailarina que não tem.

Sala sem mobília

Goteira na vasilha

Problema na família

Quem não tem 
Procurando bem,

Todo mundo tem...

(HOLANDA, 2006, p. 330).

Em discurso dotado de ferramental "naturalidade", o poeta, fingidor como ele só, assume o tom da inocência cruel das crianças, e dispara: se é para discriminar, procurando bem, todo mundo tem um ponto ridículo, vergonhoso ou reprovável a ser posto na baila. Ou seja, a realidade vem à tona intensificada, e, invertendo o ponto de partida (a particularidade da bailarina que a faria digna de admiração), constrói-se um sentimento de totalidade, uni(versali)dade, pois absolutamente ninguém é como a bailarina: logo, ela se mostra falsa, inverossímil, suspeita - ou, noutra chave, privada de uma vida verdadeira. A arte, nesse sentido, pela via dialética, desvela a pseudo-arte da bailarina, que se mantém aquém (e não além) no humano.

A revelação desta canção se confirma, ainda, na elucidação de que, numa ciranda infinita de exemplos, não seria possível atribuir a nenhuma outra causa, senão à sua multiplicidade e à sua condição de defeituoso, a graça do humano. Com isso, ridiculariza-se o fato de que só a bailarina “é que não tem". Tal conclusão ganha vulto quando observamos a noção de Lévinas (1997) acerca da "compreensão", inteligibilidade que nossa sociedade presta às alteridades. A de incorporação do diferente ao padrão do portador do estatuto de normal: "[...] inteligibilidade, entendida como solução do antagonismo do Mesmo e do Outro, não pode ter outra significação que a redução ou da conversão do Outro ao Mesmo, a partir do Outro que se presta ao Mesmo" (p. 236).

Com a constatação de que a imperfeição é traço geral do que se compreende por humano, incorporar o Outro ao Mesmo é despir o primeiro de sua alteridade para adorná-lo com as marcas do segundo, ou seja, vesti-lo das imperfeições tidas como aceitáveis ao universo deste.

Eliminar da "bailarina” (e de nós) possíveis defeitos representa, sob dois aspectos muito importantes, a própria eliminação de sua existência. O primeiro aspecto é manifesto na própria canção: "não ter coceira”, nem 
“dente com comida”, provavelmente só é possível a um corpo morto, porque o vivo é sujeito a sensações e dependente da alimentação - que invariavelmente deixa marcas no sorriso. "Falta de maneira" e "pecado" são inerentes a tudo quanto se move: o que é certo numa cultura é objeto de cuidado em outra, então, o simples fato de estar no mundo significa estar inadequado a algum de seus contextos. O conceito de pecado, por exemplo, emana das religiões. Matar e morrer por uma causa faz parte dos dogmas de certas ideologias religiosas e se, como levanta Santos (2004, p. 779), "a compreensão do mundo excede em muito a compreensão ocidental de mundo".

"Não ter medo" também merece leitura aqui: o medo é, em certa medida, uma das condições da manutenção da vida. Se a bailarina não tem medo, põe-se em ameaça, em abismo, e perde, em algum momento, para a natureza, aquilo que pretensamente acreditava invulnerável: a vida.

Esse segundo aspecto diz respeito à castração. Freud já teorizava sobre a fragilidade do processo que pretendia submeter o desejo humano às normas necessárias à unificação de um conjunto social organizado. $\mathrm{Na}$ "Ciranda..." temos a evidenciação das infelizes consequências disso: se há alguém que verdadeiramente se dedica a preencher esse perfil em todas as suas vicissitudes, com perfeição, vive em função do prazer de outrem - no caso, um olhar de menino apaixonado pela perfeição inalcançável da bailarina - ou da satisfação das normas. Zizek (2003, p. 107) emparelha tal tipo de comportamento à mensagem básica do Zen ("a libertação está na perda do Eu”), e a identifica com a completa fidelidade militar dos soldados norte-americanos, "completa obediência às ordens e cumprimento do dever, sem concessões ao Eu e a seus interesses", em detrimento, mesmo, da própria vida.

Não considerável indivíduo, mas mero títere cego, pode ser reconhecida como personagem dos sonhos, da idealização, da ilusão romântica de uma sociedade governável por normas totalmente alheias às dos desejos individuais dos sujeitos sociais. A bailarina é a personificação de uma vida perfeita, mas sem uma vida sua. Existe, na canção, como alguém que condensa o ideal do "todo mundo", mas que está acima desse 
“todo mundo". E esse acima é, numa análise rasa, o mesmo que estar fora dele (ou mesmo aquém do mundo). Conforma-se com o "ninguém" da canção, alguém cujos "ter" são precedidos de "nãos".

Pelo mecanismo da identificação, o receptor dessa canção deseja, a priori, encontrar par para si na perfeição da bailarina. Depois de análise, porém, percebe o esvaziamento de si em benefício de uma norma, e avalia o quanto não tem se prestado à obediência cega às normas em detrimento da aceitação de sua humanidade e das dos Outros. Se isso se completa, o resultado pode ser uma reavaliação das relações consigo e com o diferente.

$\mathrm{O}$ objeto arte nos fornece as senhas, ao trazer à superfície significantes pouco cotidianos que necessitam de emergir e ser arejados. Mas os significados, o berço das maravilhas que nos são reveladas pelos olhos de outrem, são frutos colhidos de nossa própria sociedade, nossa casa e nossa vida - que carecem que lhe emprestemos nossos olhos, e que mínguam à espera de cuidados nossos. A poesia musical, literária, nos empresta suas lentes, e, aponta a chance de podermos, melhor, buscar luz própria, lendo, vendo e ouvindo, de modo menos precário e indigesto, a poesia nossa de cada dia, que se nos dá hoje. A poesia, que dói na carne das personagens, das personas, das pessoas e do poeta, emerge cumprindo uma sina. E é gritante, e inquire respostas, tanto "À flor da pele" (HOLANDA, 2006, p. 236) quanto "À flor da terra" (HOLANDA, 2006, p. 237-238) ${ }^{5}$ :
O que será que será
Que dá dentro da gente e que não devia
Que desacata a gente, que é revelia
Que é feito uma aguardente que não sacia
Que é feito estar doente de uma folia
Que nem dez mandamentos vão conciliar
Nem todos os unguentos vão aliviar
Que nem todos quebrantos, toda alquimia

\footnotetext{
"À flor da pele" e "À flor da terra" são uma espécie de sequência descolada: dois poemas aplicados a mesma base musical, e gravados como canções separadas em "Meus caros amigos", no ano de 1976, mesmo ano em que foram compostas. Da colagem feita aqui, as duas primeiras estrofes compõem a canção "À flor da pele", e as demais, "À flor da terra”.
} 
Que nem todos os santos, será que será

$\mathrm{O}$ que não tem governo, nem nunca terá

$\mathrm{O}$ que não tem vergonha, nem nunca terá

$\mathrm{O}$ que não tem juízo.

O que será que me dá

Que me bole por dentro, será que me dá,

Que brota à flor da pele, será que me dá,

$E$ que me sobe às faces e me faz corar

E que me salta aos olhos a me atraiçoar

E que me aperta o peito e me faz confessar

$\mathrm{O}$ que não tem mais jeito de dissimular

E que nem é direito ninguém recusar

E que me faz mendigo, me faz suplicar

O que não tem medida, nem nunca terá

O que não tem remédio, nem nunca terá

$\mathrm{O}$ que não tem receita. ${ }^{6}$

O que será que me dá

Que me queima por dentro, será que me dá

Que me perturba o sono, será que me dá

Que todos os tremores me vêm agitar

Que todos os ardores me vêm atiçar

Que todos os suores me vêm encharcar

Que todos os meus nervos estão a rogar

Que todos os meus órgãos estão a rogar

E uma aflição medonha me faz implorar

O que não tem vergonha, nem nunca terá

O que não tem governo, nem nunca terá

$\mathrm{O}$ que não tem juízo.

O que será que será

Que andam suspirando pelas alcovas

Esclarecemos que essas duas primeiras estrofes compõem a canção "À flor da pele", e as demais, "À flor da terra", espécie de sequência descolada o mesmo poema, aplicada, inclusive, a mesma reunião de melodia e harmonia. 
Que andam suspirando em versos e trovas

Que andam combinando no breu das tocas

Que anda na cabeça, anda nas bocas

Que andam acendendo velas nos becos

Que estão falando alto pelos botecos

Que gritam nos mercados, que com certeza

Está na natureza, será que será

O que não tem certeza, nem nunca terá

O que não tem conserto, nem nunca terá

$\mathrm{O}$ que não tem tamanho.

O que será que será

Que vive nas idéias desses amantes

Que cantam os poetas mais delirantes

Que juram os profetas embriagados

Que está na romaria dos mutilados

Que está na fantasia dos infelizes

Que está no dia-a-dia das meretrizes

No plano dos bandidos, dos desvalidos

Em todos os sentidos, será que será

O que não tem decência, nem nunca terá

O que não tem censura, nem nunca terá

$\mathrm{O}$ que não faz sentido.

O que será que será

Que todos os avisos não vão evitar

Porque todos os risos vão desafiar

Porque todos os sinos irão repicar

Porque todos os hinos irão consagrar

E todos os meninos vão desembestar

$E$ todos os destinos irão se encontrar

E mesmo o Padre Eterno que nunca foi lá

Olhando aquele inferno, vai abençoar

O que não tem governo, nem nunca terá

O que não tem vergonha, nem nunca terá

O que não faz juízo. 
A arte da palavra, tecnologia, está dada. Então, que nós, aprendizes de suas lentes, façamos o dever de casa: o verbo "ser" no futuro é marca do artista, que vê mais longe. E disfarça a charada, na qual, uma vez trazida de volta para o presente, o "o que é o que é" se evidencia. E a resposta é: “poesia”.

Para retomar a brincadeira intertextual do início, pode-se, hoje ainda, crer que a mão que balança o vero é a mão que estremece o mundopara o seu próprio bem.

THE HAND THAT SWINGS THE TRUE: A PROPOSAL OF READING ON ART RECEPTION FROM THE SONGS OF CHICO BuARQUe DE HOLlanda

\section{Abstract}

From a particular view on art and the contemporary world in which we live, we propose an analysis related to the Art's participation on the subject's of this time worldview. Therefore, we highlight as a corpus a musical poetry, which we call "oraliteratura": the song by Chico Buarque de Hollanda.

KeYwords: Song (Popular Brazilian Music). Chico Buarque. Society. Contemporanity. Education.

LA MANO QUE BALANCEA EL VERO: UNA PROPUESTA DE LECTURA SOBRE LA ReCePCión de arte de las CANCIONeS de Chico Buarque de Hollanda

\section{RESUMEN}

Partiendo de una mirada particular sobre el arte y la contemporaneidad en la que vivimos, propongo un análisis relacionado con el papel que juega el arte en la cosmovisión de los sujetos de esta época. Para ello, destacamos como corpus un arte no literario, sino poesía musical, literatura oral: el canto de Chico Buarque de Hollanda.

Palabras-Clave: Canción. Chico Buarque. Sociedad. Contemporaneidad. Educación. 


\section{REFERÊNCIAS}

A MÃO que balança o berço. Curtis Hanson. Local: Estados Unidos da América; Coreia do Sul, 1992.111min (1 DVD).

ARIZA, Adonay.O Brasil local e global. In: ARIZA, Adonay. Electronic samba: a música brasileira no contexto das tendências internacionais. São Paulo: Annablume; Fapesp, 2006. p. 54-92.

BARTHES, Roland. O prazer do texto. Tradução J. Guinsburg. São Paulo: Perspectiva, 1977. (Coleção Elos).

BAKHTIN, Mikhail. Estética da criação verbal. Tradução Paulo Bezerra. São Paulo: WMF Martins Fontes, 2015.

BAKHTIN, Mikhail. Estética da criação verbal. Tradução Paulo Bezerra. São Paulo: Martins Fontes, 2013.

BAKHTIN, Mikhail. Estética da criação verbal. Tradução Paulo Bezerra. São Paulo: Martins Fontes, 2003.

BAUDRILLARD, Jean. “O objeto”. In: BAUDRILLARD, Jean. Senhas. Tradução Maria Helena Kürner. Rio de Janeiro: Difel, 2003. p. 9-12.

BERNADET, Jean Claude. O que é cinema. São Paulo: Círculo do Livro, 1980. (Primeiros Passos).

CORRÊA, Ana Laura dos Reis et al. Literatura e vida social. In: CORRÊA, Ana Laura dos Reis; HESS, Bernard Herman; ROSA, Daniele dos Santos (Org.). Cadernos de literatura: um caderno de formação em literatura na educação do campo. São Paulo: Expressão Popular, 2019. p. 11-38.

DUARTE, Newton. Arte e formação humana em Lukács e Vigotski.In: REUNIÃO ANUAL DA ANPED, 31., 2008, Caxambu. Anais... Caxambu: Anped, 2008. Disponível em: http: //www.anped.org.br/reunioes/31ra/1trabalho/GT174026--Int.pdf. Acesso em: 18 jun. 2016.

EAGLETON, Terry. Teoria da literatura: uma introdução. São Paulo: Martins Fontes, 2002.

HANSEN, João Adolfo. In: JOBIM, José Luís (Org.). Palavras da crítica: tendências e conceitos no estudo da literatura. Rio de Janeiro: Imago, 1992. p. 11-43. 
HARVEY, David. Condição pós-moderna. Tradução Adail Ubirajara Sobral. Rio de Janeiro: Ed. Loyola, 1989. p. 45-67.

HOLANDA, Chico Buarque de. Tantas palavras: Todas as letras. São Paulo: Companhia das Letras, 2006.

KRISTEVA, Julia. A revolução da linguagem poética. In: Literatura significações e ideologia. Lisboa: Arcádia. 1976. p. 104-130. (Coleção Práticas de Leitura).

LAROCHE, Maximilien. Dialectique de l'Americanisation. Quebec: Université Laval/Grelca, 1993. p. 83-102. (Coleção Essais, 10)

LÉVINAS, Emmanuel. A determinação filosófica da idéia de cultura. In: LÉVINAS, Emmanuel. Entre nós: ensaios sobre a alteridade. Coordenador de tradução Pergentino Stefano Pivatto. Petrópolis: Vozes, 1997. p. 229-239.

LOBO, Luiza. Leitor. In: JOBIM, José Luís (org.). Palavras da crítica: tendências e conceitos no estudo da literatura. Rio de Janeiro: Imago, 1992. p. 231-251.

MENESES, Adelia Bezerra de. Chico Buarque de Hollanda. São Paulo: Abril Cultural, 1980. (Literatura comentada).

MENEZES, Philadelpho. A experimentação artística na pós-modernidade. In: A crise do passado: modernidade, vanguarda, metamodernidade. São Paulo: Experimento, 1994. p. 164-171.

SANTERRES-SARKANY, Stéphane. Teoria da literatura. New York: Publicações Europa-América, 1991. (Coleção Saber).

SANTOS, Boaventura de Souza. Para uma sociologia das ausências e uma sociologia das emergências. In: SANTOS, Boaventura de Souza (org.). Conhecimento prudente para uma vida decente: um discurso sobre as ciências revisitado. São Paulo: Cortez, 2004. p. 777-815.

SAVIANI, Dermeval; DUARTE, Newton. A formação humana na perspectiva histórico-ontológica. In: SAVIANI, Dermeval; DUARTE, Newton (org.). Pedagogia histórico-crítica e luta de classes na educação escolar. Campinas: Autores Associados, 2012. p. 13-35.

UNGER, Roberto Mangabeira. Introdução. In: UNGER, Roberto Mangabeira. Paixão: um ensaio sobre a personalidade. Tradução Renato Schaeffer e Luís Carlos Borges. 2. ed. São Paulo: Boitempo, 1998. p. 9-87. 
ZIZEK, Slavoj. "De homo otarius a homo sacer". Bem vindo ao deserto do Real!: cinco ensaios sobre o 11 de setembro e datas relacionadas. Tradução Paulo César Castanheira. São Paulo: Boitempo, 2003. p. 103-132.

Submetido em 08 de outubro de 2020

Aceito em 24 de novembro de 2020

Publicado em 14 de fevereiro de 2021 